\title{
Microbially Mediated Immobilization of Contaminants Through In Situ Biostimulation: Scale up of EMSP project 55267
}

\author{
June 15, 2004
}

Philip M. Jardine

Oak Ridge National Laboratory

P.O. Box 2008

Oak Ridge, TN 37831-67038

865-574-8058

jardinepm@ornl.gov
Scott C. Brooks

Oak Ridge National Laboratory

P.O. Box 2008

Oak Ridge, TN 37831-6038

865-574-6398

brookssc@ornl.gov

Students / post grads: 1 undergraduate student

2 post-doctoral

\section{Purpose and Objectives}

The overall goal of the proposed research is to provide an improved understanding and predictive capability of the mechanisms that allow metal-reducing bacteria to be effective in the bioremediation of redox sensitive toxic metals and radionuclides. The study is motivated by the likelihood that subsurface metal-reducing bacteria can be stimulated to effectively alter the redox state of contaminants so that they are immobilized in situ for long time periods. The work described in this proposal will advance the technological and scientific needs associated with the long-term management of the enormous inground inventories of $\mathrm{Cr}, \mathrm{U}$, Tc, and Co present at numerous DOE installations throughout the country. The objectives of our project are to (1) develop an improved understanding and predictive capability of the rates and mechanisms controlling microbially mediated reduction of toxic metals and radionuclides in heterogeneous field settings, (2) quantify the impacts of hydrological and geochemical processes on the effectiveness of indigenous microorganisms to transform and immobilize radionuclides and metals in situ, (3) provide an improved understanding of the importance of microbial consortia interactions in the bacterial immobilization of radionuclides and toxic metals, and (4) determine intrinsic bioreduction rate parameters to improve our generic predictive capability of in situ microbially mediated metal reduction.

This report summarizes $3.5 \mathrm{y}$ of research for a $4.5 \mathrm{y}$ project.

Technical progress: 
In an effort to scale-up the research findings in EMSP 55267, DOE funded the peerreviewed EMSP 73784 project (renamed ERKP602 in FY03), whose principal goal was to provide an improved understanding and predictive capability of the mechanisms that allow metal-reducing bacteria to be effective in the in situ immobilization of redox sensitive contaminants in the subsurface. Our approach was to use coupled laboratory and field scale investigations to demonstrate that subsurface metal-reducing bacteria can be stimulated to effectively alter the redox state of contaminants so that they are immobilized in situ for long time periods. The current research focus has been cut short since the field site has been targeted for immediate remediation and deemed as the top cleanup prioritization for the Oak Ridge Accelerated Remediation endeavor. A summary of research progress to date includes:

\section{EMSP 55267 (FY97-99)}

In an effort to control the off-site migration of redox sensitive metals $(\mathrm{Cr})$ and radionuclides (Co, U), research within our previous EMSP project (55267) used metalreducing bacteria to stabilize contaminant plumes in laboratory scale soil columns. Our challenge was to optimize microbial reduction processes in the presence of competing geochemical oxidation and sorption reactions, and to sustain microbial reduction processes for long periods of time. Our approach involved the use of (a) a sophisticated dynamic flow technique to quantify geochemical oxidation/sorption and microbial reduction rates and mechanisms controlling the mobility of $\mathrm{U}, \mathrm{Cr}$, and Co-EDTA in heterogeneous soils/sediments, (b) novel spectrophotometric techniques to monitor the time-dependent redox transformations and immobilization of U, Cr, and Co-EDTA by subsurface media, (c) an advanced numerical model that couples hydrologicbiogeochemical transport processes for simulation of the experimental data.

Early on our research group was able to demonstrate the sustained microbial reduction of ${ }^{60} \mathrm{Co}(\mathrm{III}) \mathrm{EDTA}$ to ${ }^{60} \mathrm{Co}(\mathrm{II}) \mathrm{EDTA}$ under dynamic flow conditions (Fig. 1). The net reduction of the ${ }^{60} \mathrm{Co}(\mathrm{III}) \mathrm{EDTA}$ dominated the fate and transport of this contaminant, even in the presence of strong mineral oxidants commonly found in the subsurface (e.g. Mn- and Fe-oxides) (Fig. 1). The environmental implications of these findings are pronounced since ${ }^{60} \mathrm{Co}(\mathrm{III})$ EDTA is extremely stable and soluble, and this enhances its persistence and transport in subsurface environments. By discovering a way to keep the bacteria healthy and growing, we were able to effectively stabilize ${ }^{60} \mathrm{Co}$ (II)EDTA in a flowing subsurface system. This is advantageous from a remedial perspective since ${ }^{60} \mathrm{Co}$ (II)EDTA is a weaker complex than ${ }^{60} \mathrm{Co}(\mathrm{III}) \mathrm{EDTA}$, and therefore easier to decouple and remediate. The research findings, published by Brooks et al. (1999), provide new and important information on how to successfully implement a bioreduction strategy at the field scale. Their use of a dynamic flow system with sustained bacterial growth conditions in geochemically reactive media is consistent with contaminant migration scenarios in situ. Extensive additional experimental and numerical research on the hydrological and geochemical processes controlling $\mathrm{U}$ and $\mathrm{Cr}$ transport in ORNL, SRL, and Hanford sediments was also accomplished in EMSP 55267, but is not discussed here. Publications are listed at the end of the progress section to convey this information. 


\section{EMSP 73784 (FY00-02)}

This project was an effort to scale-up laboratory bioreduction investigations to the fieldscale. A well-characterized, highly instrumented field facility (Jardine et al., 1999, 2002) located on the Oak Ridge Reservation was used to assess the in situ bioreduction of radionuclides (Figs. 2-4).

\section{Microbiology}

- $\quad$ Microbial community dynamics of the groundwater from the field site have been characterized for direct counts (AODC), aerobic heterotrophs, anaerobic heterotrophs, fermenters ( $\mathrm{SO}_{4}{ }^{2-}$ reducers, methanogens, $\mathrm{H}_{2}$ utilizers), nitrate reducers, $\mathrm{Co}(\mathrm{III}) \mathrm{EDTA}$ reducers, $\mathrm{Fe}(\mathrm{III})$ reducers, $\mathrm{Mn}(\mathrm{IV})$ reducers, $\mathrm{SO}_{4}{ }^{2-}$ reducers, methanogens, and $\mathrm{Fe}(\mathrm{II})$ oxidizers.

- We have isolated and purified numerous metal-reducing and denitrifying bacteria from the site groundwater at various spatial locations. Over 35 metal reducing and 60 denitrifying isolates have been uniquely fingerprinted and their 16s rDNA fragments have been successfully PCR amplified, using FD1 and 1540r as primers, in an effort to determine the phylogeny affinity of the isolates. Each of the metal-reducing isolates from the field-site groundwater have been screened for Fe-citrate and Co(III)EDTA reduction.

- $\quad$ Numerous groundwater nutrient and electron donor amendment strategies were investigated in the laboratory in an effort to determine the optimal nutrient regime necessary to simulate bacteria involved in metal reduction. Various concentrations of nutrients such as ammonium and phosphate, and electron donor such as ethanol, methanol, lactate, acetate, and pyruvate, were used to stimulate growth. Each scenario was tested in time-course studies that investigated the kinetics of Co(III)EDTA reduction (Figure 1). Scenarios resulting in biostimulation produced reduction rates with time scales of hours to days which is sufficiently rapid to ensure that efficient toxic metal reduction could occur in situ within our fractured system which has rapidly moving groundwater.

- $\quad$ This project assisted with the development of novel DNA microarray chips which contain several hundred genes for use in rapid analysis of microbial community structure and activity during the biostimulation experiment.

- $\quad$ This project also assisted with cross-correlating the microarray results with conventional molecular detection methods (e.g. quantitative PCR), thus providing validation for quantitative assessment by microarray hybridization.

- $\quad$ Extensive research has focused on the roll of microbial biofilms in the simultaneous reduction of multiple terminal electron acceptors (i.e. contaminant and metal-oxides). The investigations used confocal scanning-laser microscopic 
images of cell aggregates coupled with macroscopic reduction rate experiments to confirm that active biofilms can simultaneously reduce contaminants such as Co(III)EDTA and mineral oxides such as Fe-oxide that occur concurrently in subsurface environments (Figure 1).

Field-Scale setup (WAG5 Field Facility - see task A.1 for complete description of site)

- $\quad$ Permitting for the (1) tracer injection, (2) additional well installations, (3) and a variety of legal issues has been completed, agreed upon, and signed by the State of Tennessee and local regulators and land owners (this significantly delayed the research portion of the project due to an extensive and expensive battle over perceived risk).

- $\quad$ Significant well field enhancement has been complete with the installation of 20 new multilevel sampling and nutrient/electron donor injection-recirculation wells for developing active biowalls (Figures 2-4). The wells were strategically placed upgradient and downgradient a biostimulation zone in order to monitor changes in contaminant flux and microbial community dynamics in both the fracture and matrix regime of the field facility. The new well field now has a total of 56 multilevel sampling wells to effectively assess and quantify the effectiveness of in situ biostimulation strategies for immobilizing contaminants.

- $\quad$ Field site geochemical dynamics including temperature, $\mathrm{pH}$, Eh, dissolved $\mathrm{O}_{2}$, $\mathrm{NO}_{3} / \mathrm{NO}_{2}, \mathrm{Fe}(\mathrm{III}) / \mathrm{Fe}(\mathrm{II}), \mathrm{SO}_{4}{ }^{2-} / \mathrm{S}^{2-}, \mathrm{CO}_{2} / \mathrm{CH}_{4}, \mathrm{Cl}^{-}$, major cations and anions, TOC, and alkalinity have been quantified as a function of time in both the fracture and matrix regime.

- $\quad$ Field site hydrologic and geochemical processes have been compiled and documented through publication and the design of the field scale contaminant injection and biostimulation experiment have been completed.

- $\quad$ An extensive supply of Co(III)EDTA solid phase has been produced and purified in our laboratory and it is ready for use in our field scale biostimulation experiment.

- $\quad$ The first field-scale biostimulation experiment is scheduled for mid February or early March, 2003, and will involve a sophisticated technical approach. Pending additional funds from this re-competed proposal, it is scheduled to last until Jan 2004. This is to be followed by an additional in situ experiment subject to last an additional 10 months.

Modeling

- $\quad$ Solute transport parameters and geochemical rate coefficients were obtained using laboratory solute transport data and a public domain hydrobiogeochemical code HBGC123D developed within our group, coupled with a two parameter 
estimation technique. This model was used to help design the field biostimulation experiment.

\section{EMSP 73784, ERKP602 (FY03)}

\section{Microbiology}

We have fabricated a field portable "parallel vacuum filtration device" that is capable of concentrating groundwater microbial biomass. To our knowledge no other device of similar design is available. This device can be applied to any aquatic environment in which the biomass density is low and the water is relatively clear, thus promoting the research of microbial ecology. Examples include aquatic environments such as cold seawater and highly contaminated groundwaters. In both cases, the biomass is low and the transportation of water is not always feasible. Thus, the parallel vacuum filtration device has greatly enhanced our ability to quantify microbial community structure and dynamics in the WAG 5 groundwater.

We have significantly improved our Functional Genomic Array for environmental groundwater samples from WAG5. A total of 2009 probes were designed and fabricated onto slides. These probes belong to different categories based on their sequence homology to different key genes involved in individual metabolism, such as nitrogen cycling, sulfate reduction, carbon cycling, phosphorus utilization, contamination degradation and metal resistance and oxidation. The arrays are currently being used during the field scale biostimulation experiment to follow changes in community structure and activity. The quantity of information and the time-savings associated with the array vs. classical microbiology techniques is enormous.

Some 80 strains of microbes were aerobically isolated from the WAG5 groundwater and their phylogeny affiliation and genotype identified through fingerprinting. With regard to their physiological properties in relation to metal reduction, from a total of 40 unique strains that were identified, 8 can reduce cobalt(III) under anaerobic conditions, but neither of them can reduce iron (III). Several of these cobalt reducers were identified as members of genera of Bacillus sp., Paenibacillus sp. and Caulobacter sp. The phylogeny affiliation of the rest remains undetermined. Denitrifier isolates belong to the following genus; Janthinobacterium sp., Aquaspirillum sp., Stenotrophomonas sp., Oligella sp., Brevundimonas sp., Bacillus sp., Pseudomonas sp., Dechloromonas sp., Matsuebacter sp., Variovorax sp., Caulobacter sp., Herbaspirillum sp., and Alcaligenes sp.

Nutrition regime

All conducted experiments of nutrition regime for stimulating metal reducer at WAG site used cobalt(III) as the indicator. We also qualitatively performed similar experiments using iron(III) as the metal reduction indicator and found some differences from that cobalt reduction. Basically, iron reduction was much slower than that of cobalt under same nutrition regime. Also, unlike cobalt reduction, which was inhibited by addition of phosphorus, iron reduction did not show the same trend. Instead, it was observed that the addition of nitrogen inhibited the iron reduction. Most importantly, however, is that the 
addition of electron donor (lactate, etc) alone was good enough for microbial stimulation of WAG5 groundwater with subsequent reduction of both metals.

\section{Field-scale tracer test and biostimulation experiment}

Pump test and forced gradient tracer dipole tests were conducted in an effort to determine whether a continuous "wall” of electron donor could be established in this fractured system. Pump tests indicated significant well interconnectness, however, the dip in fracture bedding planes dampened the effect. A forced gradient $\mathrm{Cl}$ dipole test confirmed that recirculation across dip was inefficient and that the majority of tracer moved along strike. The results were not unexpected, however, we were hoping for better.

Based on the above findings, we abandoned our original electron donor injection scenario and devised a multi-source injection strategy that allowed for the natural gradient injection of ethanol (our electron donor) with subsequent movement along strike (Fig. 4). The system was automated in a similar fashion as described by Jardine et al. (1999, WRR), with the modification of a $\mathrm{Br}$ tracer tag being used to trigger downhole $\mathrm{Br}$ specific ion probes as to the frequency of ethanol addition.

Microbial stimulation was rapid in the indigenous Fe-reducing environment with a $10 \mathrm{X}$ increase in biomass in all injection and downgradient monitoring wells (first $7 \mathrm{~m}$ ) within two weeks. Groundwater sulfate decreased with time with a subsequent increase in sulfide, suggesting that we were driving the system to increasing anaerobic conditions. Electron donor addition continues and the injection of up-gradient contaminant $\mathrm{Co}(\mathrm{III}) \mathrm{EDTA}$ and nonreactive tracer $\mathrm{Cl}$ has been initiated. Since the site is remote and without electricity, instrumentation is powered with solar panels and generators. Freezing temperatures have slowed the contaminant injection timeframe but the experiment is currently in full swing. The injection experiment will continue until the third week of March 2004 when we have been asked to clean up the site and shut operations down. We will continue to monitor the movement of Co-EDTA throughout the course of the year and may add ethanol manually once the automated system is terminated.

\section{Modeling}

The model HydroBioGeoChem 123D, which is a multicomponent, multiprocess flow and transport code has been calibrated to the site hydrology and geochemistry, associated with multispecies fate and transport in a fractured waste disposal site (WAG 5) at ORNL. A multiscale modeling approach, from laboratory batch and column to field scale models, on the basis of genetic evolutionary algorithms and Latin-hypercube sampling techniques is used to obtain model parameters for the field site (Figure 5). Mass transfer rates and geochemical reaction coefficients derived from the model can now be used in risk assessment models of other contaminated subsurface sites on the Oak Ridge Reservation where subsurface transport is complicated by fractured flow and matrix diffusion. We plan to use HydroBioGeoChem 123D as part of an EMSP project to simulate on-going multicomponent reactive contaminant transport and in situ bioreduction experiments at a 
waste disposal site (WAG 5) at ORNL.

\section{Implications:}

The experimental and numerical results from this research will provide knowledge and information in previously unexplored areas of in situ biostimulation for metal and radionuclide immobilization to support EM's mission of long-term isolation and in situ remediation of contaminated environments. By unraveling the fundamental mechanisms controlling the microbially mediated reduction and immobilization of contaminants in situ, we provide an enhanced opportunity for successfully implementing biostimulation strategies at numerous DOE installations that are plagued with legacy waste.

\section{b. Publications}

Peer-reviewed manuscripts from EMSP 55267, 73784, and KP602:

Jardine, P.M., R. O'Brien, Wilson, G.V., and J.P. Gwo. 1998. Experimental techniques for confirming and quantifying physical nonequilibrium processes in soils. p. 243-271. (In) H.M. Selim and L. Ma. Physical Nonequilibrium in Soils: Modeling and Application. Ann Arbor Press, Inc. Chelsea, Michigan.

Gwo, J. P., and G. T. Yeh. 1997. Application of a parallel 3-dimensional hydrogeochemistry HPF code to a proposed waste disposal site at the Oak Ridge National Laboratory. In Tentner, A. (ed.), High Performance Computing 1997: Grand Challenges in Computer Simulation, p.128-133.

Fendorf, S.E., P.M. Jardine, D.L. Taylor, and S.C. Brooks. 1999. Auto-inhibition of oxide mineral oxidative capacity toward Co(II)EDTA: Time-resolved studies using XANES spectroscopy. (In) Sparks, D.L. and T. Grundel (eds.) Kinetics and mechanisms of sorption processes at the mineral-water interface. ACS Symposium Series 715. pp. 358371.

Fendorf, S.E., P.M. Jardine, R.R. Patterson, D.L. Taylor, and S.C. Brooks. 1999. Pyrolusite surface transformations measured in real-time during the reactive transport of Co(II)EDTA. Geochim. Cosmochim. Acta. 63:3049-3057

Brooks, S.C., S.L. Carroll, and P.M. Jardine. 1999. Sustained bacterial reduction of $\mathrm{Co}$ (III)EDTA ${ }^{-}$in the presence of competing geochemical oxidation during dynamic flow. Environ. Sci. Technol. 33:3002-3011.

Jardine, P.M., S.E. Fendorf, M.A. Mayes, I.L. Larsen, S.C. Brooks, and W.B. Bailey. 1999. Fate and transport of hexavalent chromium in undisturbed heterogeneous soil. Environ. Sci. Technol. 33:2939-2944. 
Mahinthakumar, G., Gwo, J. P., and Moline G. R., 1999. Subsurface biological activity zone detection using genetic algorithms, ASCE J. of Environ. Eng. 125(2): 1103-1112.

Jardine, P.M., W.E. Sanford, J.P. Gwo, O.C. Reedy, D.S. Hicks, R.J. Riggs, and W.B. Bailey. 1999. Quantifying diffusive mass transfer in fractured shale bedrock. Water Resour. Res. 35:2015-2030.

Jardine, P.M., S.C. Brooks, G.V. Wilson, and W.E. Sanford. 2000. Basic research strategies for resolving remediation needs in contaminated fractured media. (In) Dynamics of Fluids in Fractured Rocks (ed) B. Faybishenko. Geophysical Monograph 122, p. 389-400.

Barnett, M.O., P.M. Jardine, S.C. Brooks, and H.M. Selim. 2000. Adsorption and transport of U(VI) in subsurface media. Soil Sci. Soc. Am. J. 64:908-917.

Jardine, P.M., G.V. Wilson, R.J. Luxmoore, and J.P. Gwo. 2001. Conceptual Model of Vadose-Zone Transport in Fractured Weathered Shales. (In) Conceptual Models of Flow and Transport in the Fractured Vadose Zone. U.S. National Committee for Rock Mechanics. National Research Council. National Academy Press, Washington D.C. p. 87-114.

Saiers, J.E., H. Guha, P.M. Jardine, and S.C. Brooks. 2000. Development and evaluation of a mathematical model for the transport and oxidation-reduction of CoEDTA. Water Resourc. Res. 36:3151-3165.

Guha, H. J.E. Saiers, S.C. Brooks, P.M. Jardine, and K. Jayachandran. 2001. Chromium transport, oxidation, and adsorption in manganese-coated sand. J. Contamin. Hydrol. 49:311-334.

Gwo, J.P., E.F. D’Azevedo, H. Frenzel, M. A. Mayes, G.T. Yeh, P.M. Jardine, K.M. Salvage, and F.M. Hoffman. 2001. HBGC123D: A high performance computer model of coupled hydrological and biogeochemical processes. Computers and Geosciences. 27:1231-1242.

Jardine, P.M. 2002. Radionuclides. (In) Encyclopedia of Soil Science. R. Lal (ed.) Marcel Dekker, Inc. pp 1092-1097.

Jardine, P.M., T.L. Mehlhorn, I.L. Larsen, W.B. Bailey, S.C. Brooks, Y. Roh, and J.P. Gwo. 2002. Influence of hydrological and geochemical processes on the transport of chelated-metals and chromate in fractured shale bedrock. J. Contamin. Hydrol. 55:137159.

Barnett, M.O., P.M. Jardine, and S.C. Brooks. 2002. U(VI) adsorption to heterogeneous subsurface media: Application of a surface complexation model. Environ. Sci. Technol. 36:937-942. 
Jardine, P.M., T.L. Mehlhorn, Y. Roh, and W.E. Sanford. 2003. Hydrological and geochemical processes controlling the fate and transport of contaminants in fractured bedrock. (In) W.L. Kingery and H.M. Selim (eds.) Geochemical and Hydrological Reactivity of Heavy Metals in Soils. CRC Lewis Publishers. Boca Raton, FL.

Lenczewski, M., P.M. Jardine, L. McKay, and A. Layton. 2003. Natural attenuation of trichloroethylene (TCE) in fractured shale bedrock. J. Contamin. Hydrol. 64(3-4):151168.

Jardine, P.M. 2004. Soil Chemistry and Mineralogy: Kinetic Models (In) Encyclopedia of Soils in the Environment. D. Hillel (ed.) Academic Press, London, UK (in press).

Gwo, J.P. and P.M. Jardine. 2004. Determining hydraulic and advective mass transfer parameters of a fractured waste disposal site: a two pore region model. Hydrogeology Journal (in press).

Jardine, P.M., T.L. Mehlhorn, S.E. Fendorf, and S.C. Brooks. 2003. Geochemical processes governing the fate and transport of $\mathrm{Cr}(\mathrm{III})$ and $\mathrm{Cr}(\mathrm{VI})$ in soils and sediments. Soil Sci. Soc. Am. J. (in preparation).

Zhang, C.L., S.C. Brooks, P.M. Jardine, and H. Vali. 2003. Factors affecting microbial uranium reduction implications for bioremediation. Proceedings of the National Conference on Environmental Science and Technology.September 8-10, 2002 . Greensboro, North Carolina (in press).

Published abstracts and presentations from EMSP 55267, 73784, and KP602:

Fendorf, S., P.M. Jardine, and S.C. Brooks. 1997. Sorption induced inhibition of redox reactions involving manganese oxides. American Chemical Society. San Francisco, CA. April 13-17.

Mayes, M.A., O.C. Reedy, I.L. Larsen, S.C. Brooks, and P.M. Jardine. 1997. Multispecies contaminant transport in undisturbed columns of weathered fractured shale. American Society of Agronomy. Anaheim, CA. Oct. 26-31.

Sanford, W.E., and P.M. Jardine. 1997. Examining diffusion with multiple tracers to aid remediation of contaminated sites. American Society of Agronomy. Anaheim, CA. Oct. 26-31.

Mehlhorn, T.L., P.M. Jardine, S.C. Brooks, S.E. Fendorf, and J.E. Saiers. 1997. Geochemical processes governing the fate and transport of $\mathrm{Cr}(\mathrm{III})$ and $\mathrm{Cr}(\mathrm{VI})$ in soils. American Society of Agronomy. Anaheim, CA. Oct. 26-31.

Brooks, S.C., and P.M. Jardine. 1997. Bacterial reduction of toxic metals during dynamic flow. American Society of Agronomy. Anaheim, CA. Oct. 26-31. 
Mayes, M.A., O.C. Reedy, I.L. Larsen, S.C. Brooks, and P.M. Jardine. 1997. Multispecies contaminant transport in undisturbed columns of weathered fractured shale. Geologic Society of America Oct.

Jardine, P.M., G.V. Wilson, W.E. Sanford, and R.J. Luxmoore. 1998. Exploring subsurface transport mechanisms in fractured media at laboratory and field scales. Conference on "Mass transport in fractured aquifers and aquitards" Geological Institute, Unversity of Copenhagen, Denmark, May 14-16, 1998.

Zhang, C., S. Brooks, S. Fendorf, and P. Jardine. 1998. Microbial uranium reduction and biomineralization: implication for immobilization of toxic metals and radionuclides. 17th annual meeting for International Mineralogical Association, Toronto, August.

Jardine, P.M. 1998. Can basic research on contaminant transport be used to improve the design of remedial strategies? Proceedings of "School of Environmental Science and Technology". Buenos Aires, Argentina. August 24-28.

Guha, H., J.E. Saiers, P.M. Jardine, and S.C. Brooks. 1998. Development and evaluation of a mathematical model for oxidation, sorption, and transport of Co(II)EDTA ${ }^{2-}$. American Geophysical Union, Dec. 6-10, 1998, San Francisco, CA.

Gwo, J. P., and P. M. Jardine, Complexity in Hydrobiogeochemistry: A Multidisciplinary Integrative Approach, A minisymposium, the Fifth SIAM Conference on Mathematical and Computational Issues in the Geosciences, March 24-27, 1999, San Antonio, Texas (http://hbgc.esd.ornl.gov/pubs/siam99/).

Jardine, P.M., T.L. Mehlhorn, I.L. Larsen, S.C. Brooks, J.P. Gwo, G.V. Wilson, and W.E. Sanford. 1999. Basic research strategies for resolving remediation needs in contaminated fractured subsurface media. Symposium on Dynamics of Fluids in Fractured Rocks: Concepts and Recent Advances. Lawrence Berkeley National Laboratory. February 610, 1999, Berkeley, CA.

Frenzel, H., M. A. Mayes, J. P. Gwo, P. M. Jardine, and G. T. Yeh, 1999. Application of a hydrobiogeochemistry computer model to fate and transport of co-contaminants in fractured saprolite, AGU Fall Meeting, December 13-17, 1999, San Francisco, California.

Gwo, J. P., H. Frenzel, M. A. Mayes, and B. J. Sieve, 2001, Determining hydrogeochemical parameters for the fate and transport of CdEDTA and CoEDTA in fractured sparolite using HBGC123D. Eleventh Annual V. M. Goldschmidt Conference, May 20-24, 2001, Hot Springs, VA.

Jardine, P.M., T.L. Mehlhorn, I.L. Larsen. 2001. Quantifying time-dependent physical and chemical processes that influence the migration of chelated radionuclides in fractured shale. Fractured Rock 2001. March 26-28, 2001, Toronto, Ontario, Canada. 
Jardine, P.M., M.A. Mayes, T.L. Mehlhorn, and S.C. Brooks. 2001. Reactive transport of chelated radionuclides through weathered shale saprolite: Observations from lab and field experimentation. Goldschmidt 2001 conference. May 20-24, Hot Springs, VA.

Jardine, P.M., M.A. Mayes, T.L. Mehlhorn, S.C. Brooks, and S.E. Fendorf. 2001. Influence of hydrological and geochemical processes on reactive contaminant transport in fractured subsurface media. Sixth International Conference on the Biogeochemistry of Trace Elements. July 29- August 2, Guelph, Ontario, Canada.

Gwo, J.P., and P.M. Jardine. 2002. Multiple scale fluid mass transfer calibration for a fracture flow model. American Geophysical Union, May 28-31, 2002. Washington D.C.

C. E. Bagwell, L. Wu, D. K. Thompson, X. Liu, T. Yan, J. M. Tiedje, and J. Zhou.2002. Development and Performance of Functional Gene Microarrays for Sensitive Detection and Quantification of Microbial Community Structure and Function. 102nd General Meeting of the American Society for Microbiology.

Gwo, J. P., M. A. Mayes, and P. M. Jardine, 2002. Reactive Transport in Fractured Saprolite: Determining Diffusive Mass Transfer and Surface Reaction Kinetics Parameters, Goldschmidt Conference Abstracts 2002, p.A300, 2002.

Mehlhorn, T.L., P.M. Jardine, and S.C. Brooks. 2003.Field-scale Transport of Chelated Metals in Contaminated Fractured Shale Bedrock American Chemical Society, September 7-11, New York, NY.

Gao, W., Z. Yang, P.M. Jardine, M. W. Fields, J. Zhou. 2004. Biomass recovery, highmolecular-weight DNA isolation and metagenomic DNA cloning library construction from groundwater and soil samples. 104th American Society of Microbiology. New Orleans, LA, May 23-27, 2004

Gwo, J.P., and P.M. Jardine, Multiscale Heterogeneity and Solute Transport Model Parameter Uncertainty Study for a Fractured Low-Level Nuclear Waste Disposal Site in the Eastern United States, AGU 2003 Fall Meeting, San Francisco, Dec. 8 - 12. 
Figure 2

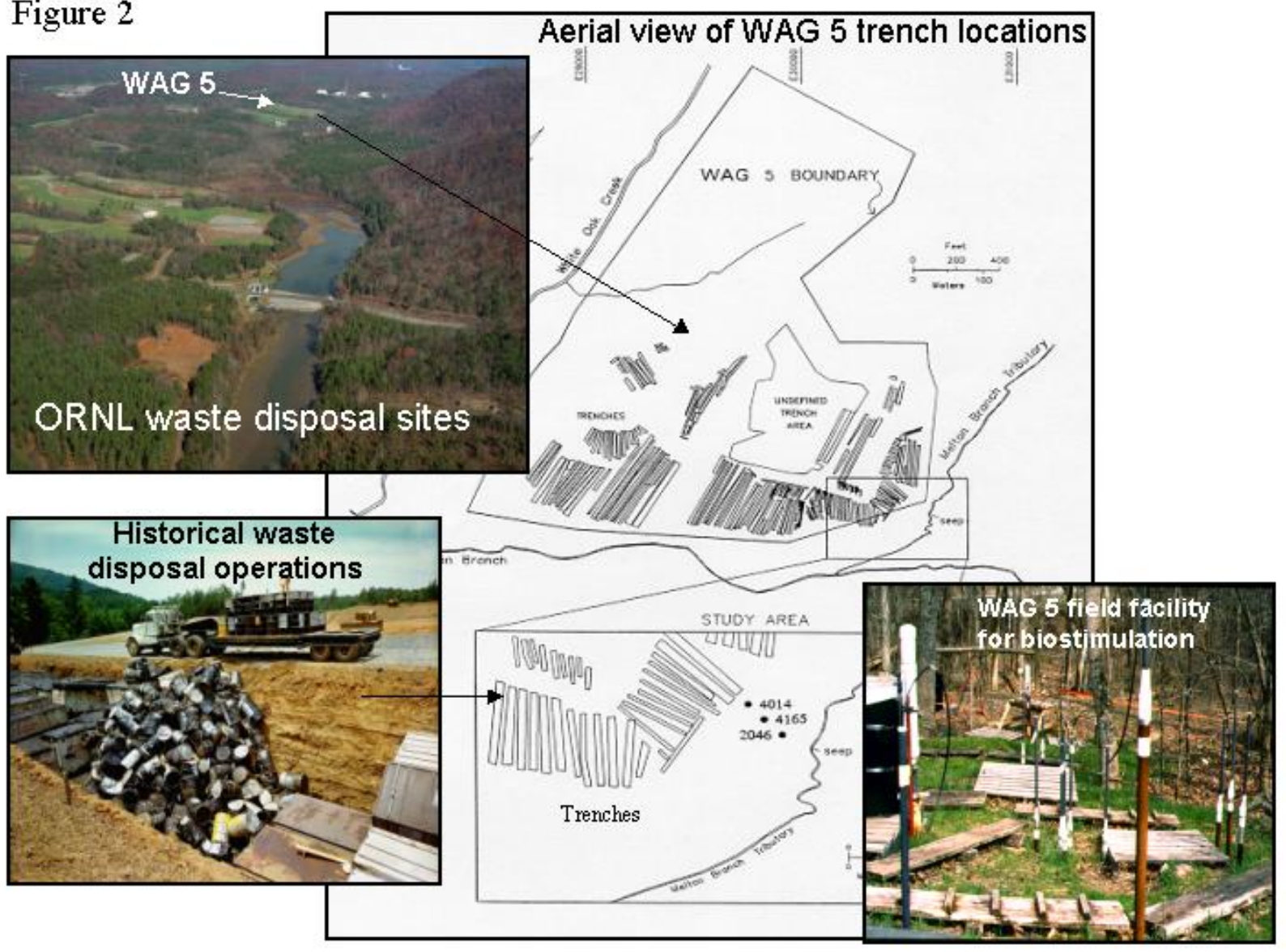

